\title{
38. EXCHANGE OF ASTRONOMERS (ÉCHANGE DES ASTRONOMES) \\ (Committee of the Executive Committee)
}

PRESIDENT: P.M. Routly

VICE-PRESIDENT: D. A. MacRae

ORGANIZING COMMITTEE: J. Delhaye, G. S. Khromov, A. Reiz, J. Sahade, F. G. Smith, F. B. Wood

During the period covered by this report, 1 January 1973 to 31 December 1975, a total of 9 general inquiries and 47 formal applications for travel grants were received. Of the latter, 21 grants were actually awarded. The names of the recipients, their countries of origin, and the organizations or areas visited, are given below:

$\begin{array}{lll}\text { Name } & \text { From } & \text { To } \\ \text { I. H. Naqvi } & \text { Canada } & \text { Canada (back from Denmark) } \\ \text { M. H. Gokhale } & \text { India } & \text { India (back from The Netherlands) } \\ \text { S. M. Jakate } & \text { India } & \text { Toronto, Canada } \\ \text { S. P. Tarafdar } & \text { India } & \text { Cardiff, Wales } \\ \text { D. Rees } & \text { Australia } & \text { Meudon, France } \\ \text { Il-Seong Nha } & \text { U.S.A. } & \text { South Korea } \\ \text { H. Schleicher } & \text { Germany } & \text { Sacramento Peak, U.S.A. } \\ \text { V. Erceg } & \text { Yugoslavia } & \text { Victoria, Canada } \\ \text { A. Bhatnagar } & \text { India } & \text { Big Bear, U.S.A. } \\ \text { Kwan-Yu Chen } & \text { U.S.A. } & \text { Poland } \\ \text { M. S. Vardya } & \text { India } & \text { Netherlands } \\ \text { V. Caloi } & \text { Italy } & \text { Columbia U., U.S.A. } \\ \text { R. C. Smith } & \text { England } & \text { Toronto, Canada } \\ \text { E. Athanassoula-Georgala } & \text { Greece } & \text { Mt. Stromlo, Australia } \\ \text { R. K. Manchanda } & \text { India } & \text { Southampton, England } \\ \text { J. W. Robertson } & \text { Australia } & \text { Steward Obs., Arizona } \\ \text { J. Smolinski } & \text { Poland } & \text { Victoria, Canada } \\ \text { K. Tanaka } & \text { Japan } & \text { Cal. Inst. of Tech, U.S.A. } \\ \text { J. R. Albano } & \text { Argentina } & \text { Cambridge, England } \\ \text { L. E. Cram } & \text { France } & \text { Sacramento Peak, U.S.A. } \\ \text { J. L. A. Francey } & \text { Australia } & \text { Oxford, England }\end{array}$

In response to rising costs of travel, the value of the average grant has nearly doubled over previous years. Further, demand has been almost exclusively for grants to help cover travel costs of long trips rather than short ones. Accordingly, to conserve the Commission's resources as far as possible, the criteria for the awarding of grants, established in previous years and reaffirmed by Commission 38 at the last IAU Meeting in Australia, were strictly applied.

These criteria include the requirement that each candidate have a definite plan of research or study which he cannot advantageously pursue in his own country, that he be far enough along in his education to have made a professional commitment to astronomy, that his proposed visit have the endorsement of the Directors at both the candidate's Home Institution and the Host Institution, and that he have no alternative means of travel support. Further, to better achieve the long-range educational objectives of the Exchange Program, it has been found necessary to insist that each candidate execute a single visit to a single Host Institution, and that each visit last at least three months.

In summary, the Commission's resources were used to award travel grants to candidates only - support for living expenses or per diem, travel grants to dependents, or funds to attend meetings, symposia, etc.; international or domestic, were specifically excluded.

Those interested in applying for a Commission 38 travel grant may do so by writing the President of the Commission and supplying him with the following documents and/or information: 
(1) A professional vita, including a short but specific account of the project or research to be carried out.

(2) A reasonably detailed itinerary including date of departure and duration of stay abroad.

(3) A letter from the Director of the Home Institution expressing his agreement with the proposed trip.

(4) A similar letter from the Director of the Host Institution.

(5) The amount of money applied for.

It is a pleasure to acknowledge the most generous and efficient support and cooperation of the General Secretary and his Staff. 